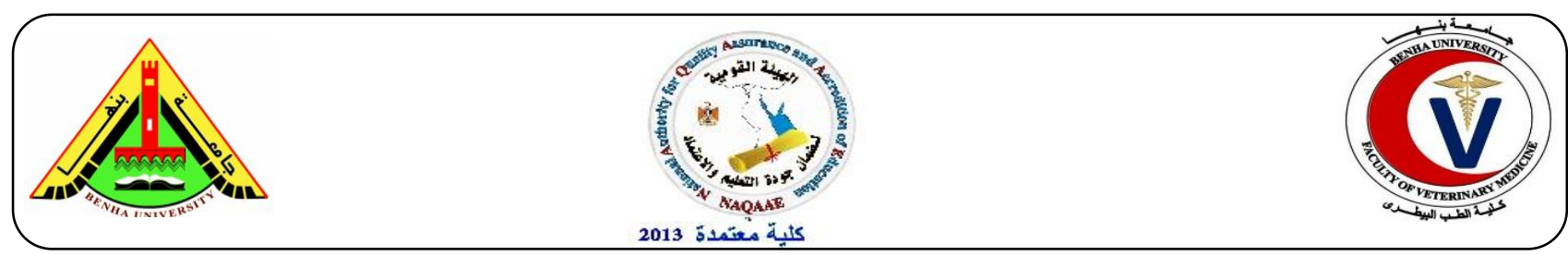

\title{
Effect of in Ovo Injection of MyoPro Gene on Growth Parameter in Fayoumi
}

\section{Chicken}

\author{
M. M. Abdel-Gawad ${ }^{1}$, M.E. Azab ${ }^{1}$, R.S. Ismail ${ }^{1}$, A. A. Nafeaa ${ }^{1}$ and . M.E. A. El-Magd \\ ${ }^{1}$ Physiology Department, Faculty of Veterinary Medicine, Benha University, Egypt \\ ${ }^{2}$ AnatomyDepartment, Faculty of Veterinary Medicine, Kafrelsheikh University. Egypt
}

\section{ABSTRACT}

The current study aimed at evaluation the effects of in ovo injection of the myostatin inhibitor, myostatin pro-peptide (MyoPro) gene on growth performance of Fayoumi chicken. A total number of 200 Fayoumi fertilized pure breed eggs were obtained from EL-Tkamoly poultry project - EL-Azab - Fayoum. Eggs were divided into two equal groups. Group 1(control group, $n=100$ ) was injected with saline, and group 2 (treated group, $\mathrm{n}=100$ ) injected with Myo-pro gene. Growth parameters were recorded (body weight, body weight gain, feed consumption per group was measured for calculating feed conversion ratio). The obtained results revealed that injection of myo-pro to Fayoumi eggs resulted in highly significant increase in body weight and weight gain during all experimental period when compared with control group. Feed conversion ratio of Myo-pro injected group was significantly lower than control group. However, food intake showed no significant change between the two groups. From the obtained results, injection of Myo-Pro gene causing marked increase in body weight gain and improvement in feed conversion ratio without change in food intake in fayoumi chicken.

Keywords: Fayoumi chicken, in Ovo-adminstration, MyoPro, body weight.

\section{INTRODUCTION}

Recently, animal meat is the main source of protein in Egypt. Chickens are source of cheap and high quality animal proteins. Different local and foreign chicken breeds are reared in farms (on large scale) and at homes (small scale) all over the country. The only two pure native breeds are Fayoumi and Dandarawi. Fayoumi is the most important Egyptian native chicken breed which recently spreads to many countries worldwide ELHossari (1996). Pure Fayoumi is known for wildness in that it is free scavenging flighty, aggressive, escape artist, quick feathering and precocious. This native breed has the carcass characteristics and flavor desired by Egyptian consumers and adapted to adverse environmental conditions including many infectious diseases as compared to foreign strains (broilers) (Tixier-Boichard 2009). However, because their growth rate and meat production are very poor when compared to broilers, breeding of local chickens is rare in farms and so their meat production is insufficient for our needs.

With advent of molecular genetics, it becomes possible to significantly improve the meat production of animals through using of biotechnological approach to transfer valuable 
genes or to block myogenesis inhibitor to produce chickens with high production (superior). Myostatin, a member of the transforming growth factor $\beta$ (TGF- $\beta)$ superfamily, is a negative regulator of skeletal muscle growth in mammals, and loss or inhibition of myostatin signaling dramatically increases muscle mass (McPherron et al., 1997).

The myostatin pro-peptide (MyoPro) is known to bind and inhibit myostatin both in vitro and in vivo. In two independent studies, (Yang et al. 2001) and (Lee and McPherron 2001) created transgenic mice that overexpressed the MyoPro. This resulted in an increase of body weight (17-30\%) and muscle mass $(22-44 \%)$ due to increase in muscle fibre diameter and number. The dramatic increase of muscularity displayed in the transgenic mice over-expressing MyoPro suggests that direct administration of recombinant MyoPro to animals may also promote muscle growth. Indeed, injection of recombinant MyoPro into neonates or adult mice resulted in significant weight increase of individual muscles within short time (Wolfman et al., 2003).

In advanced countries, gene transfer succeeded to increase meat production and genetic improvement of chickens. However, in Egypt we still use the traditional methods (growth promoters and phenotype selection) mainly due to lack of facilities and experiences. These traditional methods failed to solve the problem of meet shortage and also failed to genetically improve our valuable local strains of chickens.

The current study aimed at evaluation the effects of in ovo injection of the myostatin inhibitor, myostatin pro-pepetide (MyoPro) gene on growth performance of Fayoumi chicken

\section{Materials AND Methods}

\section{II-1.Experimental design}

A total number of 200 of pure breed chicken fertilized eggs of the native Egyptian breed, Fayoumi_obtained from EL-Tkamoly poultry project - EL-Azab in Fayoum Governorate. eggs divided into two equal groups. Group 1control group injected with saline, and group 2 (treated group) was injected with MyoPro gene which was obtained from Prof. Ketan Patel, Reading University, Reading, UK.

\section{II-2.Preparation of gene and gene injection as} described by (Morgan and Fekete, 1996):

Ligation of the MyoPro to shuttle vector (Slax12NCO) to give ClaI- ClaI flanking region then Insertion of ClaI- MyoPro - ClaI by standard subcloning techniques into retro viral vectors derived from SR-A strain of Rous sarcoma virus (RCAS) at the virus' single ClaI site. Inject the MyoPro gene with virus into eggs at the age of 3-5 day after incubation. The needle was inserted in the PSM under the labelled ectodermal layer. If the tip of the needle was in the sub-embryonic space, the inoculum diffused rapidly. The needle tip was slowly withdrawn until it was in the presomatic mesoderm (PSM). At this point, the flow from the needle became slow. While the needle tip was slowly withdrawn, about $0.1 \mu$ l viral stock was slowly injected. To assure the distribution of RCAS-MyoPro throught all precursor of skeletal muscles. The injection was done in the developing chick embryo at the region will form the muscle, which called somites, using a very small needle fitted on a micromanipulator (micropipettes that an outer diameter of less than $10-15$ microns about $0.1 \mu \mathrm{l}$ stock was slowly injected) 


\section{II-3 Birds and housing}

Birds were allowed ad libitum access to food and fresh water. A commercial balanced broiler starter ration (from Elkhawas company) containing $22 \%$ crude protein and metabolizable energy of about 3000 (K. $\mathrm{cal} / \mathrm{kg}$ ) was used for feeding of the young birds. While growing chicks (from 4 weeks of age) were fed diet containing $20 \%$ crude protein and $3015 \mathrm{kcal} / \mathrm{Kg}$ metabolizable energy, Ca $2.25 \%$ and Available Phosphorus $0.44 \%$. As shown in Table 1.

\section{II-4.Growth parameters}

The chicks were weighed individually at the start of experiment, then every week for recording the live body weights(W0-W6) then every 2 weeks from W6-W12, food intake was measured every 3 weeks during W0-W6 then every 2 weeks from (W6-W12), and body weight gains (differences between each two successive weights).
The feed conversion rate was calculated by dividing the food intake on average body gain in body weight.

\section{II-5. Statistical analysis}

Results are expressed as mean \pm standard error (SE). Differences between means in different groups were tested for significance using a t test, using the statistical package for social science (SPSS) and $P$ value of 0.05 or less was considered significant.

\section{III.Results}

Collectively, all transgenic (myostatin $^{-/}$) chicks at different time points (from hatching to $12 \mathrm{w})$ had significant $(\mathrm{P}<0.05)$ higher body weight (Table 2, 3). and bogy weight gain than the control group (Table 4, 5).

Food intake of the injected group $\left(\right.$ myostatin $^{--}$) did not significantly change in the amount was noticed and wild type chicken (Table 6) so, The feed conversion ratio was significantly decreased $(\mathrm{P}<0.05)$ in Myostatin ${ }^{-}$ /- as compared to control chicken (Table 7). 
Table 1: Composition of the ration was as the following:

\begin{tabular}{lcc} 
& \multicolumn{2}{c}{ Ration } \\
Ingredients & Starter & Growing \\
Maize (\%) & 54 & 62 \\
Soya bean meal, 44 \% CP (\%) & 33 & 22 \\
Concentrate (\%) & 10 & 10 \\
Wheat bran (\%) & 3 & - \\
Limestone (\%) & - & 5.7 \\
Sodium chloride (\%) & - & 0.3 \\
Calculated nutrient content & & \\
Metabolizable energy (kcal/Kg) & 3000 & 3015 \\
Crude protein $(\%)$ & 22 & 20 \\
Methionine $(\%)$ & 0.46 & 0.648 \\
Cysteine $(\%)$ & 0.325 & 0.257 \\
Methionine + Cysteine $(\%)$ & 0.211 & 0.211 \\
Crude fiber $(\%)$ & 3.60 & 3.41 \\
Crude fat $(\%)$ & 6.40 & 5.91 \\
Linoleic acid $(\%)$ & 1.37 & 1.45 \\
Calcium $(\%)$ & 0.84 & 2.25 \\
Available phosphorus $(\%)$ & 0.49 & 0.44
\end{tabular}

Concentrates providing the following per kilogram of diet: crude protein $520 \mathrm{~g}$; vitamin A $120000 \mathrm{IU}$; vitamin E $100 \mathrm{mg}$; vitamin $\mathrm{K}_{3} 21 \mathrm{mg}$; vitamin $\mathrm{B}_{1} 10 \mathrm{mg}$; vitamin $\mathrm{B}_{2} 40 \mathrm{mg}$; vitamin $\mathrm{B}_{6}$ $15 \mathrm{mg}$; pantothenic acid $100 \mathrm{mg}$; vitamin $\mathrm{B}_{12} 0.1 \mathrm{mg}$; Fe $0.3 \mathrm{mg}$; Mn $600 \mathrm{mg}$; Cu $50 \mathrm{mg}$; Co 2 mg; Se1 mg and $\mathrm{Zn} 450 \mathrm{mg}$. 
Table2: Effect of in ovo injection of MyoPro on live body weight ( $\mathrm{g}$ ) of male Fayoumi chicken (means \pm standard errors).

\section{Group}

\begin{tabular}{|c|c|c|}
\hline Weeks & $\begin{array}{c}\text { Control } \\
\text { Males }\end{array}$ & $\begin{array}{l}\text { Myostatin }^{-/-} \\
\text {males }\end{array}$ \\
\hline W0 & $21.25^{\mathrm{b}} \pm 0.95$ & $40.5^{\mathrm{a}} \pm 1.25$ \\
\hline W1 & $66^{\mathrm{b}} \pm 0.57$ & $140.33^{\mathrm{a}} \pm 1.88$ \\
\hline W2 & $116.6^{b} \pm 0.87$ & $244.33^{\mathrm{a}} \pm 2.33$ \\
\hline W3 & $173.81^{b} \pm 1.74$ & $345.65^{\mathrm{a}} \pm 15.5$ \\
\hline W4 & $226.42^{b} \pm 0.86$ & $474.33^{\mathrm{a}} \pm 2.33$ \\
\hline W5 & $286^{b} \pm 0.57$ & $604.33^{\mathrm{a}} \pm 2.33$ \\
\hline W6 & $376.25^{b} \pm 1.58$ & $744.5^{\mathrm{a}} \pm 17.3$ \\
\hline W8 & $551.5^{\mathrm{b}} \pm 1.74$ & $1005.4^{\mathrm{a}} \pm 15.8$ \\
\hline W10 & $664.9^{b} \pm 1.42$ & $1263.8^{a} \pm 19.1$ \\
\hline W12 & $889.4^{\mathrm{b}} \pm 2.4$ & $1650.7^{\mathrm{a}} \pm 34.2$ \\
\hline
\end{tabular}

Means with different letters at the same row differ significantly at $(\mathrm{P}<0.05)$. 
Table3: Effect of in ovo injection of MyoPro on live body weight (g) of female Fayoumi chicken (means \pm standard errors).

\section{Group}

\begin{tabular}{|c|c|c|}
\hline & $\begin{array}{l}\text { Control } \\
\text { females }\end{array}$ & $\begin{array}{c}\text { Myostatin }^{-/-} \\
\text {Females }\end{array}$ \\
\hline \multicolumn{3}{|c|}{ weeks } \\
\hline W0 & $20.72^{b} \pm 1.05$ & $38.5^{\mathrm{a}} \pm 1.15$ \\
\hline W1 & $60.56^{\mathrm{b}} \pm 0.86$ & $115.62^{\mathrm{a}} \pm 1.45$ \\
\hline W2 & $103.33^{b} \pm 1.76$ & $195.33^{\mathrm{a}} \pm 1.45$ \\
\hline W3 & $144.7^{b} \pm 11.15$ & $292.84^{\mathrm{a}} \pm 12.36$ \\
\hline W4 & $203.76^{b} \pm 2.33$ & $422.33^{\mathrm{a}} \pm 1.45$ \\
\hline W5 & $263.67^{b} \pm 2.33$ & $557.33^{\mathrm{a}} \pm 1.67$ \\
\hline W6 & $320.6^{\mathrm{b}} \pm 13.2$ & $682.4^{\mathrm{a}} \pm 15.6$ \\
\hline W8 & $500.7^{b} \pm 11.2$ & $928.5^{\mathrm{a}} \pm 12.3$ \\
\hline W10 & $608.2^{\mathrm{b}} \pm 14.8$ & $1179.3^{\mathrm{a}} \pm 16.3$ \\
\hline W12 & $714.5^{b} \pm 29.8$ & $1425.8^{\mathrm{a}} \pm 31.5$ \\
\hline
\end{tabular}

Means with different letters at the same row differ significantly at $(\mathrm{P}<0.05)$. 
Table 4 : Effect of Myostatin Inhibition On Body Weight gain (g) of male Fayoumi chicken (means \pm standard errors)

Group

Weeks

Week 1

Week 2

Week3

W0-W3

Week 4

Week 5

Week 6

W3-W 6

Week 8

Week 10

Week 12
Control males

$44.58^{\mathrm{b}} \pm 0.51$

$50.6^{b} \pm 0.30$

$104^{\mathrm{a}} \pm 1.52^{\mathrm{a}}$

$55^{\mathrm{b}} \pm 0.1 .9$

$44.58^{b} \pm 0.51$

$54.8^{b} 1 \pm 1.82$

$126.45^{\mathrm{a}} \pm 3.2$

$59.58^{b} \pm 0.29$

$130^{\mathrm{a}} \pm 2.88$

$81.03^{b} \pm 0.65$

$140.83^{\mathrm{a}} \pm 1.9$

$202.44^{b} \pm 6.2$

$398.85^{\mathrm{a}} \pm 11.2$

$175.25^{b} \pm 5.8$

$260.9^{\mathrm{a}} \pm 8.5$

$113.4^{\mathrm{b}} \pm 4.9$

$258.4^{\mathrm{a}} \pm 9.0$

$224.5^{b} \pm 8.2$

Means with different letters at the same row differ significantly at $(\mathrm{P}<0.05)$. 
Table 5 : Effect of Myostatin Inhibition On Body Weight gain (g) of female Fayoumi chicken (means \pm standard errors)

\section{Group}

Weeks

Week 1

Week 2

Week3

W0-W3

Week 4

Week 5

Week 6

W3-W 6

Week 8

Week 10

Week 12
Control

females

$39.99^{\mathrm{b}} \pm 1.08$

$42.76^{\mathrm{b}} \pm 0.906$

$41.9^{\mathrm{b}} \pm 1.4$

$123.98^{\mathrm{b}} \pm 5.3$

$58.43^{\mathrm{b}} \pm 2.5$

$60^{\mathrm{b}} \pm 4.04$

$56.866^{\mathrm{b}} \pm 2.5$

$175.9^{\mathrm{b}} \pm 6.2$

$180.1^{\mathrm{b}} \pm 4.9$

$107.5^{\mathrm{b}} \pm 3.6$

$106.3^{b} \pm 7.5$ $125.13^{\mathrm{a}} \pm 1.27$

$389.56^{\mathrm{a}} \pm 10.5$

$250.8^{\mathrm{a}} \pm 9.1$

\section{Femles}

Myostatin $^{-/-}$

Females

$76.5^{\mathrm{a}} \pm 1.36$

$80.5^{\mathrm{a}} \pm 1.36$

$97.5^{\mathrm{a}} \pm 1.36$

$254.44^{\mathrm{a}} \pm 8.7$

$130.72^{\mathrm{a}} \pm 2.29$

$135^{\mathrm{a}} \pm 2.03$

$246.1^{\mathrm{a}} \pm 7.4$

$246.5^{\mathrm{a}} \pm 11.5$

Means with different letters at the same row differ significantly at $(\mathrm{P}<0.05)$. 
Table 6: Effect of Myostatin inhibition on feed intake (g)/ one chick of Fayoumi chicken (means \pm standard errors).

\begin{tabular}{lcr}
\multicolumn{1}{l}{ Group } & Myostatin $^{-/-}$ & Control \\
Weeks & $298.2 \pm 8.2$ & $262.5 \pm 7.9$ \\
W0-W3 & $508.2 \pm 10.5$ & $449.4 \pm 9.4$ \\
W3-W6 & & \\
W6-W8 & $551.6 \pm 11.3$ & $501.0 \pm 11.5$ \\
W8-W10 & & $625.8 \pm 12.8$ \\
W10-W12 & $655.2 \pm 13.5$ & $858.9 \pm 14.3$
\end{tabular}

Table 7 : Effect of Myostatin inhibition on feed conversion ratio of Fayoumi chicken ( means \pm standard errors).

$\begin{array}{lcc}\begin{array}{l}\text { Group } \\ \text { Weeks }\end{array} & \text { Myostatin }^{-/-} & \text {Control } \\ \text { W0-W3 } & 0.98^{\mathrm{b}} \pm 0.05 & 1.72^{\mathrm{a}} \pm 0.17 \\ \text { W3-W6 } & 1.27^{\mathrm{b}} \pm 0.09 & 2.22^{\mathrm{a}} \pm 0.29 \\ \text { W6-W8 } & 2.11^{\mathrm{b}} \pm 0.18 & \\ \text { W8-W10 } & 2.53^{\mathrm{b}} \pm 0.24 & \\ & & \\ & 2.31^{\mathrm{b}} \pm 0.32 & \\ \text { W10-W12 } & & 4.56^{\mathrm{a}} \pm 0.51 \\ \end{array}$

Means with different letters at the same row differ significantly at $(\mathrm{P}<0.05)$. 


\section{DISCUSSION}

The present study showed that in ovo injection of myo-pro gene caused highly significant increase in body weight and body weight gain. Similar results were recorded by Jianag et al., 2017 in mice that AAV-MPRO/FC gene (Adeno-associated virusmediated expression of myostatin propeptide) transfer could make hyperglycemia and increase body mass. Several studies were done by myostatin inhibitors in cattle. These showed muscle doubling (Kambadur et al., 1997 , McPherron \&Lee, 1997, Rodgers \&Garikipati, 2008) and showed muscular hyperplasia (Wegner et al., 2000)

There is no previous studies using Myo pro in chicken so the present work considered the first trail in chicken However, Lee et al., (2017) using Cas9 as myostatin inhibitor in chicken tissue The observed marked .culture increase in body weight and body weight gain in Myo-pro injected group may be attributed to myostatin which is the most powerful inhibitor for skeletal muscle development (McPherron et al., 1997) which is expressed in skeletal muscle (throughout life, from the early stages to late adulthood) and to some extent in fat tissue, heart and mammary tissues. Therefore, of this gene inhibition experimentally will cause severe increase in muscle growth (double muscling) in some cattle.
To the best of our knowledge this is the first study to demonstrate increase of Fayoumi chicken live body weight and body weight gain after injection of MyoPro gene as a specific inhibitor for myostatin activity

Increased body weight may be due to increase of weight skeletal muscles collectively called meat) because muscles make up a large proportion of the body weight approximately 40\%) (Steven, 1991). Moreover, myostatin inhibition has the stimulatory role on muscle growth and development (McPherron et al., 1997). The latter author observed increase in diameter and number of muscle fiber after inhibition of myostatin. Earlier studies have attributed the increase in body weight to muscle hypertrophy in knockout mice exhibit approximately $11 \%$ more muscle fibers with $43 \%$ larger fiber cross sectional area (Amthor et al. 2009).

Suppression of myogenesis by preventing proliferation and differentiation of muscle precursors and myoblasts through inhibition of Pax3, MyoD, and MyoG (Amthor et al., 2002, Joulia et al., 2003, Hayashi et al., 2008 and Muroya et al., 2009. Binding regions for muscle growth related transcription factors MyoD were identified in the promoter of myostatin gene (Salerno et

al. 2004). 
The marked increase in body weight and body weight gain that observed -after myo pro gene injection in this study may be attributed to change in some anabolic hormones such as growth hormone and IGF-1 as reported by Liu et al. (2003) who showed increase in growth hormone level after myostatin inhibition.

The present work showed that myostatin-/- group cause improvement in feed conversion ratio without significant change in food intake.

There is no pervious study on the effect of myo-pro gene injection on food intake and feed conversion ratio. The marked improvement in feed conversion ratio may be attributed to increase in anabolic hormonal changes

\section{CONCLUSION}

Injection of Myo-Pro gene causing marked increase in body weight and body weight gain with improvement in feed conversion ratio without change in feed intake of Fayoumi chicken.

\section{REFERENCES}

Amthor, H., A. Otto, A. Vulin, A. Rochat, J. Dumonceaux, L. Garcia, E. Mouisel, C. Hourdé, R. Macharía, M. Friedrichs, F. Relaix, P. S. Zammit, A. Matsakas, K. Patel \& T. Partridge (2009) Muscle hypertrophy driven by myostatin blockade does not require stem/precursor-cell activity. Proceedings of the National Academy of Sciences of the United States of America, 106, 7479- 7484.
Amthor, H., R. Huang, I. McKinnell, B. Christ, R. Kambadur, M. Sharma \& K. Patel (2002) The regulation and action of myostatin as a negative regulator of muscle development during avian embryogenesis. Dev Biol, 251, 24157.

El-Hossari, M. A. (1996): Improvement of Egyptian poultry local breeds. The Egyptian Society of Poultry Science, Alexanderia University 14 March 1996.

Hayashi, S., M. Miyake, K. Watanabe, H. Aso, S. Hayashi, S. Ohwada \& T. Yamaguchi (2008) Myostatin preferentially down-regulates the expression of fast $2 \mathrm{x}$ myosin heavy chain in cattle. Proc Jpn Acad Ser B Phys Biol Sci, 84, 354-62.

Jiange,

J.G,

Shen,G.F,Li,J.,Qiao,C.,Xiao,B., Yan,

H., wang,

D.w andXiao,X.(2017)Adeno-associated virus-mediated expression of myostatin propeptide improves the growth of skeletal muscle and attenuates hyperglycemia in $\mathrm{db} / \mathrm{db}$ mice. Gene therapy 24,167175@2017Macmilan_publishers limited, part of spring Nature.0969$7128 / 17$

Joulia, D., H. Bernardi, V. Garandel, F. Rabenoelina, B. Vernus \& G. Cabello (2003) Mechanisms involved in the inhibition of myoblast proliferation and differentiation by myostatin. Exp Cell Res, 286, 263-75.

Kambadur, R., Sharma, M., Smith, T.P., Bass, J.J., 1997. Mutations in myostatin (GDF8) in double-muscled Belgian Blue and Piedmontese cattle. Genome research 7, 910-916.

Lee, J. H, Kim,S.W. and Park,T.S. 2017: Myostatin gene knockout mediated by Cas9-D10A nickase in chicken DF1 
cells without off-target effect. AsianAustralas J Anim Sci Vol. 30, No. 5:743-748

https://doi.org/10.5713/ajas.16.0695pI SSN 1011-2367 eISSN 1976-5517

Liu, W., S. G. Thomas, S. L. Asa, N. Gonzalez-Cadavid, S. Bhasin \& S. Ezzat (2003) Myostatin is a skeletal muscle target of growth hormone anabolic action. $J$ Clin Endocrinol Metab, 88, 5490-5496.

McPherron, A. C., A. M. Lawler \& S. J. Lee 1997 Regulation of skeletal muscle mass in mice by a new TGF-beta superfamily member. Nature, 387, 8390.

McPherron, A.C., Lee, S.J., 1997. Double muscling in cattle due to mutations in the myostatin gene. Proc Natl Acad Sci U S A 94, 12457-12461.

Morgan, B. A., \& Fekete, D. M. (1996). Manipulating gene expression with replication-competent retroviruses. Methods Cell Biol, 51, 185-218.

Muroya, S., K. Watanabe, S. Hayashi, M. Miyake, S. Konashi, Y. Sato, M. Takahashi, S. Kawahata, Y. Yoshikawa, H. Aso, K. Chikuni \& T. Yamaguchi (2009) Muscle typespecific effect of myostatin deficiency on myogenic regulatory factor expression in adult double-muscled Japanese Shorthorn cattle. Anim Sci J, 80, 678-85.

Rodgers, B.D., Garikipati, D.K., 2008. Clinical, agricultural, and evolutionary biology of myostatin: a comparative review. Endocrine reviews 29, 513534.

Salerno, M. S., M. Thomas, D. Forbes, T. Watson, R. Kambadur \& M. Sharma (2004) Molecular analysis of fiber type-specific expression of murine myostatin promoter. Am J Physiol Cell Physiol, 287, 1031-1040.
Stevens, L.(1991):Genetics and evolution of the domestic fowl. SF492.S74 1991 636.5'0821 ic20 91-9211 -ISBN 0521 40317 cambridge press.

Tixier-Boichard, M., Bordas, A. and Rognon, X. (2009) characterization and monitoring of poultry genetic resources. World's Poultry Science Journal., 65, 272-285.

Wegner, J., Albrecht, E., Fiedler, I., Teuscher, F., Papstein, H.J., Ender, K., 2000. Growth- and breed-related changes of muscle fiber characteristics in cattle. Journal of animal science 78, 14851496.

Wolfman, N. M., A. C. McPherron, W. N. Pappano, M. V. Davies, K. Song, K. N. Tomkinson, J. F. Wright, L. Zhao, S. M. Sebald, D. S. Greenspan \& S.-J. Lee (2003) Activation of latentmyostatin by the BMP-1/tolloid family of metalloproteinases. Proc. Natl. Acad. Sci. USA, 100, 1584215846.

Yang, J., T. Ratovitski, J. P. Brady, M. B. Solomon, K. D. Wells \& R. J. Wall (2001) Expression of myostatin pro domain results in muscular transgenic mice. Mol Reprod Dev, 60, 351-61. 